\title{
What If Piketty Is Right? Real Economic Costs of Rising Income Inequality
}

\author{
By
}

Thomas R. Gottschang

December 2016

COLLEGE OF THE HOLY CROSS, DEPARTMENT OF ECONOMICS

FACULTY RESEARCH SERIES, PAPER NO. 16-20*

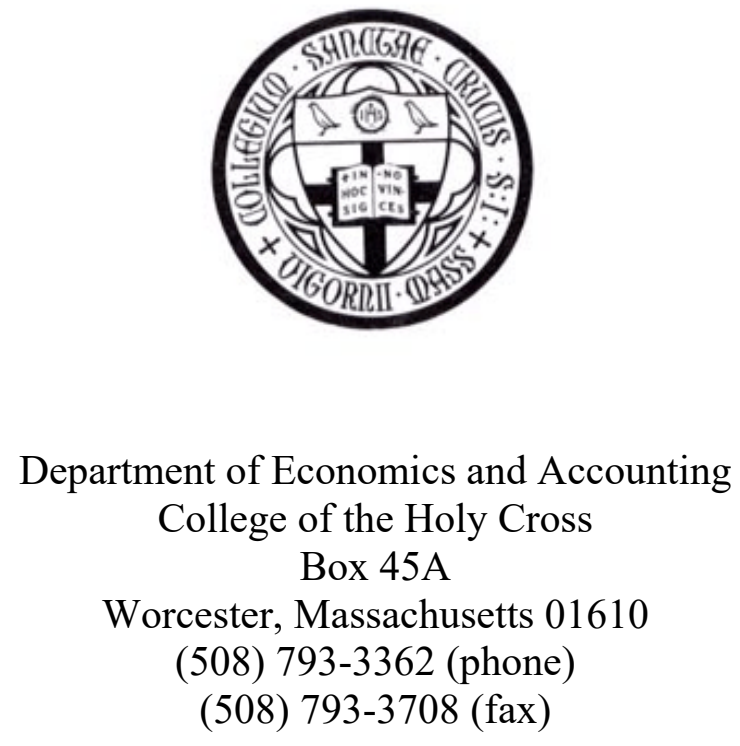

https://www.holycross.edu/academics/programs/economics-and-accounting

*All papers in the Holy Cross Working Paper Series should be considered draft versions subject to future revision. Comments and suggestions are welcome. 


\title{
What If Piketty Is Right? Real Economic Costs of Rising Income Inequality
}

\author{
By \\ Thomas R. Gottschang ${ }^{\dagger}$ \\ College of the Holy Cross
}

December 2016

\begin{abstract}
Thomas Piketty's analysis of income and wealth distribution, Capital in the Twenty-First Century, argues that wealth has become increasingly concentrated in the hands of the most affluent, while lower and middle class real incomes have stagnated; he warns that this trend could have "potentially terrifying" results, possibly even violent revolution. This article presents evidence that growing inequality weakens the entire economy by eroding the purchasing power of the vast majority of the population and the education of the labor force, while increasing its vulnerability to future collapses of the financial markets. It agrees with Piketty's concern that the capitalist market system, driven by Adam Smith's classic reliance on the pursuit of individual self-interest, lacks mechanisms to correct these distortions, which must be addressed by new policy initiatives.
\end{abstract}

JEL Classification Codes: D63

Keywords: income inequality

Published as: Thomas R. Gottschang, (2016), "What If Piketty Is Right? Real Economic Costs of Rising Income Inequality," Perspectives on Political Science, Vol. 46:1, pp. 11-15, http://dx.doi.org/10.1080/10457097.2016.1203229

†Department of Economics, Box 152A, College of the Holy Cross, Worcester, MA 01610-2395, 508-793-2678 (phone), 508-793-3710 (fax), tgottsch@holycross.edu 
In his wide-ranging historical analysis of the distribution of income and wealth in the industrialized countries, Capital in the Twenty-First Century (hereafter CITC; all parenthetic page citations refer to this book), Thomas Piketty argues that since the 1980s wealth has become increasingly concentrated in the hands of the most affluent members of society, while lower and middle class real incomes have stagnated. While Piketty warns that the trends he has identified could have "potentially terrifying" results, possibly even violent revolution (263), he says little about more immediate consequences of rising inequality that adversely affect all levels of the economy. This paper will present evidence that the growing imbalance in income distribution weakens the economy by eroding its foundations in the purchasing power of the vast majority of the population and the education of the labor force, while simultaneously increasing its vulnerability to future collapses of the financial markets. The great concern for Piketty is that this trend appears to emerge legitimately within the capitalist market system, calling into question the validity of Adam Smith's classic argument that the pursuit of individual self interest will ultimately guide an economy, as "by an invisible hand,"1 to outcomes that best serve all elements of the population. In Piketty's words, “... there is no natural, spontaneous process to prevent destabilizing, inegalitarian forces from prevailing permanently." (CITC, 20-21)

Piketty is not opposed to capitalism, nor does he advocate socialism, commenting that he has "no interest in denouncing inequality or capitalism per se - especially since social inequalities are not in themselves a problem as long as they are justified" (30). In his conclusion, he comments that one way to redress growing income disparities would be to simply place high taxes on income from capital. He rejects this approach, however, as likely to reduce investment and thereby retard growth of the real economy and of average labor income (572). Although Piketty shows that the proportion of national wealth owned by the highest 10 percent of the 
population has risen dramatically since the 1980s, he acknowledges that living standards for the entire populace have also improved, as measured by higher life expectancies, better education and health care, and access to technologies like cell phones, the internet, and air travel (90-95). Moreover, Piketty's conclusions are derived from observation of the historical data he has accumulated, not from economic theory. Indeed, he emphasizes that "one should be wary of any economic determinism in regard to inequalities of wealth and income" (20).

The argument presented here is that a high concentration of wealth introduces distortions that prevent markets from allocating resources to their most productive uses, due to higherincome individuals pursuing their self-interest. Income inequality is an inherent element of the classical economic market model. Efficiency is achieved in the market by directing resources natural resources ("land"), labor of all kinds, and manufactured productive assets ("capital") - to their most valuable uses by paying more for more productive resources and less for less productive ones. Adam Smith described the principle as follows: "Every individual is continually exerting himself to find out the most advantageous employment for whatever capital he can command. ... But the study of his own advantage naturally, or rather necessarily, leads him to prefer that employment which is most advantageous to the society." ${ }^{2}$ The system inevitably generates higher incomes for people who have skills or resources or assets that produce more valuable products. This source of efficiency is threatened, however, if the influence that accompanies higher incomes results in changes to laws, regulations, taxation practices, and government spending priorities that unduly favor the wealthy and cause compensation to be diverted away from its most productive use. Piketty maintains that our understanding of the problem is hindered by the fact that academic economists - the members of the intellectual community who should be responsible for analyzing and evaluating the nature of income 
distribution - generally fall into the top ten percent of the income hierarchy. It is therefore not surprising that many of them "believe that the economy of the United States is working fairly well and, in particular, that it rewards talent and merit accurately and precisely" (296-297).

While Piketty acknowledges that his data may contain flaws and that the trends he identifies could reverse themselves in the years to come, his conclusions are consistent with numerous recent reports and studies of income and wealth distribution. A prominent example is a report in the Federal Reserve Bulletin of September, 2014 on information from the Survey of Consumer Finances, which finds that although real family incomes rose on average by four percent between 2010 and 2013, virtually all of the growth was among the highest income groups, while low-income families saw their real incomes decline. ${ }^{3}$ The study also observes that the share of total wealth held by the top three percent of families rose from just under 45 percent in 1989 to over 54 percent in 2013.

\section{Poverty and Consumer Spending}

Low or negative income growth for less wealthy consumers is problematic for the economy as a whole because low-income families spend more of any additions to their incomes than do affluent people, who allocate much of their income increases to savings. ${ }^{4}$ In an opinion column published in the New York Times in January, 2013, Nobel Prize-winning economist Joseph Stiglitz argued that "inequality is holding back the recovery." Further concentration of wealth and the new income it generates at the upper end of the income distribution at the expense of poor and middle groups results in weakened demand in product markets, restraining growth and innovation. Although it is true that the savings of higher income groups help to fuel investment in new firms and expansion of old ones, the stimulative impact on the economy of 
saving and investment takes longer than new purchasing power does. Furthermore, the incentive for new investment is to meet growing demand for products, which has to come from new spending, not additional saving. Piketty notes that the sharp rise in inequality in the United States after 1980 helped lay the groundwork for the collapse of the financial markets in 2008. As the fruits of economic growth shifted to the wealthiest decile of the population, the remaining 90 percent saw their real incomes rise by less than one half of one percent each year, resulting in "virtual stagnation of the purchasing power of the lower and middle classes in the United States" (297) .

\section{Poverty and Education}

The most troubling long-term impact of rising income disparities is the damage done to the education of children in lower-income families. On October 17, 2014, in a speech at the Federal Reserve Bank of Boston, Federal Reserve Chair Janet Yellen referred to the Federal Reserve Bulletin of September, 2014 and expressed concern over the widening gaps in incomes and wealth holdings in the American population. ${ }^{6}$ Yellen noted that the decline in resources available to low-income families hinders their ability to educate their children. The U.S. Census Bureau reports that in 2014 , the poverty rate for children in the United States was 21.1 percent, almost half again larger than the rate of 14.8 percent for the population as a whole. ${ }^{7}$ Yellen's concerns reflect an extensive body of literature that finds multiple negative effects of poverty on early education. Children in poor families are more likely to be malnourished, to be exposed to disease, and to have less access to good schools. On average, their parents spend less time reading with them and are more likely to be poorly educated themselves. Empirical studies have identified a strong correlation between family income levels and educational achievements of 
children, particularly among the very poor. ${ }^{8} \mathrm{~A}$ recent study that examines the effects of changes in the earned income tax credit on educational results estimates that in very poor households, "a $\$ 1,000$ increase in family income raises math and reading test scores by about six percent of a standard deviation."

In addition to the negative effects on education of poverty at the family level, community average income levels are closely related to the quality of public education. A report by the General Accounting Office (GAO) in 1995 found that children from low-income families were most likely to attend schools with deficient facilities. A more recent report that surveyed public school construction across the United States between 1995 and 2004 found that the wealthiest school districts spent nearly twice as much per pupil on building facilities $(\$ 9,361)$ as the poorest school districts $(\$ 4,800) \cdot{ }^{10}$ Many impoverished families face a multigenerational cycle in which parents are poor because they are poorly educated, and their children will be poorly educated because their families are poor.

The increased concentration of wealth documented by Piketty weakens public education because it enables high-income groups to bring substantial pressure to bear on politicians to decrease their tax burdens, reducing the funds available for public schools. Today, most states are still spending less per pupil than they did before the Great Recession, despite the substantial recovery of the economy, and in the face of the sharp rise in incomes of the wealthiest segments of society. Neither the states nor the federal government have been able to legislate adequate increases in tax revenues. ${ }^{11}$ The cost to the economy of reductions in the availability and quality of public education is that the abilities of many bright children in poor families are not fully developed, thereby reducing the pool of talented labor that is the most important resource of any society. And while Piketty concludes that educational differences alone cannot account for the 
full range of income disparities, he emphasizes that the best way to improve the earning potential of low-income workers is for them to acquire the education and training that will raise their productivity (304-310). Thus a weakening of public education damages the entire economy while exacerbating the problem of inequality.

\section{Deregulation of Financial Markets}

Finally, perhaps the most clearly damaging consequence of greater wealth concentration is that with greater financial resources at their disposal, high-income groups are able to exert tremendous pressure to weaken regulation of the financial markets. According to fundamental market principles, the intelligent pursuit of self-interest by any group in society should benefit the entire economy. As Adam Smith explained in his famous passage, "It is not from the benevolence of the butcher, the brewer, or the baker that we expect our dinner, but from their regard to their own interest." ${ }^{12}$ In the case of modern financial markets, however, that invaluable insight is less applicable than it was to eighteenth-century butchers and brewers. The narrow pursuit of short-term personal gain by the wealthy through increasingly complex and intertwined financial instruments can result in catastrophic collapses of the financial system that drag down the entire economy. The Great Depression and the crash of 2008 are only the most dramatic examples of many in the grim list of financial bubbles and crashes that punctuate modern economic history. Piketty contends that in the years before 2008 , "there is absolutely no doubt that the increase of inequality in the United States contributed to the nation's financial instability" (CITC, 297). Low-income households took on increasing debt after 1980, as their real incomes failed to grow. The loans were supplied by banks and finance companies that in some cases were unscrupulous and which all faced fewer regulatory constraints than in the past. 
The regulatory environment of the early 2000s was the result of years of lobbying by financial firms, resulting in legislation that steadily removed constraints and weakened supervision of the financial markets. An interesting example of both antiregulatory legislative efforts and the potential for economists to adopt the goals of high-income groups is the career of former Senator Phil Gramm. ${ }^{13}$ Gramm earned a doctorate in economics at the University of Georgia and taught at Texas A \&M University from 1967 to 1978 . He was then elected representative to Congress from Texas for two terms and served as Senator from 1985 to 2002. During his years in the Senate Gramm chaired the Banking Committee and was known as "one of the chief architects of a comprehensive deregulation of the financial rules in the late 1990s." ${ }^{.14}$ After Gramm retired from the Senate in 2002 he was hired as a lobbyist by the Swiss bank UBS. The best-known result of Gramm's efforts was the 1999 Gramm-Leach-Bliley Act, repealing the Glass-Steagall Act (formally the "Banking Act of 1933"), which was intended to maintain a separation between commercial banks and securities firms, in order to protect bank deposits from the risks of securities trading. Another of Gramm's accomplishments was the Commodity Futures Modernization Act of 2000, which reduced regulation of financial derivatives and is considered to have contributed to the expansion of mortgage backed securities that eventually caused the collapse of the housing market. ${ }^{15}$

Thanks to the efforts of anti-regulation legislators like Senator Gramm, and their own ingenuity, financial firms were able to exploit gaps in the law and expand the operations of financial intermediaries that were unregulated, such as hedge funds, thus creating massive pools of obscure financial instruments in markets that were neither supervised nor transparent. ${ }^{16}$ When the crash came, the entire financial system proved to be fatally infected with large holdings of bad debt, much of it in the form of mortgage-backed securities. In brief, the big banks and other 
financial intermediaries successfully evaded regulation and created a nearly impenetrable mass of interconnected and often poorly documented derivatives and obligations, which ultimately required years to unravel.

After the financial markets collapsed - an event generally dated to the fall of the Lehman Brothers investment bank in September 2008 - the U.S. Treasury stepped in to re-capitalize suddenly insolvent major banks through the Troubled Asset Relief Program (TARP) and forced other banks to strengthen their balance sheets by raising new capital on their own. ${ }^{17}$ The Federal Reserve had already begun to make loans to banks on an unprecedented scale, and to pick up the essential short-term commercial lending market that had completely collapsed. ${ }^{18}$ The Fed also introduced the systematic purchase of large amounts of mortgage-backed securities from the banks in order to restore health to their balance sheets, in the program known as "quantitative easing." The quantitative easing purchases did not end until October, 2014, by which time the Federal Reserve held over 1.2 trillion dollars worth of mortgage-backed securities. In other words, deregulation of the financial markets resulted in a crisis that plunged the entire economy into a decline that required extraordinary rescue measures by Federal financial authorities.

Following the financial collapse, Congress developed legislation intended to reduce the risk of similar events in the future. The result was the Dodd-Frank Wall Street Reform and Consumer Protection Act ("Dodd-Frank"), signed into law in July 2010. The main purpose of Dodd-Frank is to bring transparency and accountability to financial markets so that investors, depositors, and taxpayers can understand how their money is being used and so that banks and other financial intermediaries will operate responsibly. As soon as the law was enacted, leading financial firms, some of whose employees are near the top of the income distribution, began to pressure Congress to weaken it. In December, 2014, Congress passed a compromise bill that 
funded most government operations through September, 2015. The compromises included a provision to eliminate an element of Dodd-Frank that required banks to move trading in high-risk derivatives out of divisions that are covered by Federally funded deposit insurance. ${ }^{19}$ The bill (H.R. 83) was signed into law by President Barack Obama on December 16, 2014. ${ }^{20}$

With the convening of the new Congress in January, 2015, bills were promptly introduced to further diminish the ability of Dodd-Frank to enforce transparency and prudence in the financial markets. ${ }^{21}$ Among the experts invited to address the House Financial Services Committee during its review of Dodd-Frank in 2015 was former Senator Phil Gramm. ${ }^{22}$ Although these efforts initially made little headway, the debate gained new momentum on June 2, 2016, when Representative Jeb Hesarling, of Texas, current Chairman of the House Financial Services Committee, delivered a speech in New York proposing a new plan for reform of the financial markets, including the elimination of substantial portions of Dodd-Frank. ${ }^{23}$ The plan is considered unlikely to succeed during the remainder of the Obama administration, but it could be adopted by a future administration and reflects the unrelenting pressure to weaken regulation of the financial markets that is at least partially the result of the high and rising concentration of wealth that Piketty documents.

\section{Conclusion}

At times the public discussion of Piketty's work bears a resemblance to the climate change debate, in the sense that some critics reject his data, while others are suspicious of his motives. And just as climate-change deniers who live near the sea have to pay attention to rising tide levels, regardless of their beliefs, so critics of Piketty cannot ignore the fact that his evidence of rising income inequality agrees with reports from a broad range of government agencies and 
academic studies. Whatever Piketty's motives, it would be prudent to consider policy changes that could begin to reverse the trend. It is contrary to the interests of everyone, from all levels of the income hierarchy, for the economy to be slowed by sluggish markets for goods and services, weakened by an undereducated labor force, and threatened with system failure by a financial industry that seems eager to repeat the practices that brought about the collapse of its own markets in 2008. Adam Smith's dictum that the economy operates most effectively when each person is allowed to pursue his rational self-interest remains valid when personal interest is seen in the broader context of an economy in which today's individual benefit is the result of actions taken by many people over the course of many years.

\section{Notes}

${ }^{1}$ Adam Smith, An Inquiry into the Nature and Causes of the Wealth of Nations (Public Domain, Kindle Edition: 2012), Book IV, Chapter ii.

${ }^{2}$ Ibid.

3 Jesse Bricker, Lisa J. Dettling, Alice Henriques, JoanneW. Hsu, Kevin B.Moore, John Sabelhaus, Jeffrey Thompson, and Richard A.Windle, "Changes in U.S. Family Finances from 2010 to 2013: Evidence from the Survey of Consumer Finances," Federal Reserve Bulletin 100.4 (September 2014).

${ }^{4}$ See Christopher D.Carroll, Jiri Slacalek, and Kiichi Tokuoka, "The Distribution of Wealth and the Marginal Propensity to Consume," European Central Bank, Household Finance and Consumption Network, Working Paper Series No. 1655, March, 2014; Luc Arrondel, Pierre 
Lamarche, and Frederique Savignac, "Wealth Effects on Consumption Across the Wealth Distribution: Empirical Evidence,” European Central Bank, Working Paper Series, No. 1817 (June 2015); Tullio Jappelli and Luigi Pistaferri, "Fiscal Policy and MPC Heterogeneity," American Economic Journal: Macroeconomics 6.4 (2014), 107-136.

5 Joseph E. Stiglitz, "Inequality is Holding Back the Recovery," New York Times, January 19, 2013.

${ }^{6}$ Binyamin Appelbaum, "Janet Yellen Warns of Inequality Threat," New York Times, October $17,2014$.

${ }^{7}$ Carmen DeNavas-Walt and Bernadette D. Proctor, Income and Poverty in the United States: 2014, U.S. Census Bureau, Current Population Reports, P60-252 (Washington, DC: U.S. Government Printing Office, 2015).

${ }^{8}$ See Anna Aizer, Shari Eli, Joseph Ferrie, and Adriana Lleras-Muney, "The Long-Run Impact of Cash Transfers to Poor Families," American Economic Review 106.4 (2016),935-971.

${ }^{9}$ Gordon B. Dahl and Lance Lochner, "The Impact of Family Income on Child Achievement: Evidence from the Earned Income Tax Credit," American Economic Review 102.5 (2012), 1927-1956.

${ }^{10}$ Mary W. Filardo, Jeffrey M. Vincent and Ping Sung, Growth and Disparity: A Decade of U.S. Public School Construction (Research Report). $21^{\text {st }}$ Century School Fund, 2006 (ED498100).

11 Michael Leachman, Nick Albares, Kathleen Masterson and Marlana Wallace, "Most States Have Cut School Funding, and Some Continue Cutting” (Report), Center on Budget and Policy Priorities, January 25, 2016 (http://www.cbpp.org/research/state-budget-and-tax/most-stateshave-cut-school-funding-and-some-continue-cutting).

${ }^{12}$ Smith, Wealth of Nations, Book I, Chapter ii . 
${ }^{13}$ Biographical Directory of the United States Congress, http://www.bioguide.congress.gov/ (accessed April 21, 2016).

${ }^{14}$ Michael J. de la Merced, "Deregulator of Banks Set to Testify Before House," New York Times, July 27, 2015.

15 Ibid.

${ }^{16}$ See James Walsh, “The Disparity Bubble: How Inequality Fed the Financial Crisis,” Kennedy School Review, No. 12, April 1, 2012, 38-40.

${ }^{17}$ See David Leonhardt,_"A Rescue That Worked, but Left a Troubled Economy,” New York Times, May 12, 2014.

${ }^{18}$ Matthew Koepke, “The Federal Reserve's Influence over Excess Reserves,” Economic Trends, Federal Reserve Bank of Cleveland, April 29, 2011 (Online).

${ }^{19}$ Kristina Peterson, Michael R. Crittendon, and Siobhan Hughes, “U.S. Lawmakers Agree on \$1.1 Trillion Spending Bill: Measure Would Fund Most Of The Government Through September And Avert Shutdown,” Wall Street Journal, December 9, 2014.

20 Jessica Tollestrup, “Congressional Action on FY2015 Appropriations Measures,” Congressional Research Service, March 9, 2015, 12, https://www.fas.org/sgp/crs/misc/R43776.pdf (accessed June 13, 2016).

${ }^{21}$ Gretchen Morgenson, "Kicking Dodd-Frank in the Teeth,” New York Times, January 11, 2015, Sunday Business, 1-2.

${ }^{22}$ De la Merced, "Deregulation of Banks."

${ }^{23}$ Victoria Finkle, "Jeb Hensarling Plan Rekindles Debate as Republicans Aim to Dismantle Dodd-Frank," New York Times, June 7, 2016, Business, Dealbook. 